\title{
Identifying groundwater recharge connections in the Moscow (USA) sub-basin using isotopic tracers and a soil moisture routing model
}

\author{
Jasper Candel ${ }^{1,2}$ • Erin Brooks ${ }^{3}$ - Ricardo Sánchez-Murillo ${ }^{4}$ - George Grader ${ }^{5}$. \\ Roel Dijksma ${ }^{1}$
}

Received: 4 October 2015 / Accepted: 22 May 2016 / Published online: 22 June 2016

(C) The Author(s) 2016. This article is published with open access at Springerlink.com

\begin{abstract}
Globally, aquifers are suffering from large abstractions resulting in groundwater level declines. These declines can be caused by excessive abstraction for drinking water, irrigation purposes or industrial use. Basaltic aquifers also face these conflicts. A large flood basalt area $\left(1.1 \times 10^{5} \mathrm{~km}^{2}\right)$ can be found in the Northwest of the USA. This Columbia River Basalt Group (CRBG) consists of a thick series of basalt flows of Miocene age. The two major hydrogeological units (Wanapum and Grand Ronde formations) are widely used for water abstraction. The mean decline over recent decades has been $0.6 \mathrm{~m}_{\text {year }}{ }^{-1}$. At present day, abstraction wells are drying up, and base flow of rivers is reduced. At the eastern part of CRBG, the Moscow sub-basin on the Idaho/ Washington State border can be found. Although a thick poorly permeable clay layer exists on top of the basalt aquifer, groundwater level dynamics suggest that groundwater recharge occurs at certain locations. A set of wells and springs has been monitored bi-weekly for 9 months for $\delta^{18} \mathrm{O}$ and $\delta^{2} \mathrm{H}$. Large isotopic fluctuations and $d$-excess values close to the meteoric water line in some wells are indicating that recharge occurs at the granite/basalt interface through lateral flow paths
\end{abstract}

Roel Dijksma

roel.dijksma@wur.nl

1 Hydrology and Quantitative Water Management Group, Wageningen University, Wageningen, The Netherlands

2 Soil Geography and Landscape Group, Wageningen University, Wageningen, The Netherlands

3 Biological \& Agricultural Engineering, University of Idaho, Moscow, ID, USA

4 National University of Costa Rica, Heredia, Costa Rica

5 PRISEM Geoconsulting, 823 W 2nd Ave, Spokane, WA 99203, USA in and below the clay. A soil moisture routing (SMR) model showed that most recharge occurs on the granitic mountains. The basaltic aquifer receives recharge from these sedimentary zones around the granite/basalt interface. The identification of these types of areas is of major importance for future managed-aquifer recharge solutions to solve problems of groundwater depletion.

Keywords Stable isotopes · USA · Basalt aquifers · Groundwater recharge/water budget $\cdot$ Numerical modelling

\section{Introduction}

Declining groundwater levels are a global concern, as a large part of the human population depends on fresh water from aquifers (UNESCO 2009). Van Loon et al. (2016) showed that humans are an important factor in the causes of droughts and the depletion of reservoirs. The depletion of reservoirs is mainly a result of groundwater pumping for drinking-water supply (Willis and Garrod 1998), irrigation (Amelung et al. 1999; Foster et al. 2004; Konikow and Kendy 2005; Hoque et al. 2007; Qureshi et al. 2010; Wada et al. 2012) and industrial use (Hayashi et al. 2009). Globally, groundwater withdrawal amounts to $750-800 \mathrm{~km}^{3}$ year ${ }^{-1}$ and exceeds annual recharge in many places of the world (Shah et al. 2000).

Urgent action is needed to slow down the depletion of groundwater reservoirs. Currently, managed aquifer recharge (MAR) methods are available to recover depleted aquifers (Dillon 2005; Maliva et al. 2014). Examples are known from many aquifers in the world - e.g. Burdekin Delta and AngasBremer area in Australia (Gerges et al. 2002; Dillon 2009); Satlasana and Kodangipalayam in India (Gale et al. 2006); and the Columbia River Basalt Group aquifer in USA (Eaton et al. 2009). However, in order to improve the success of MAR 
projects (Gale et al. 2006), advanced aquifer characterization is needed to identify suitable locations for MAR practices (Dillon 2005; Rahman et al. 2012; Maliva et al. 2014). Basaltic aquifers which are widely used for water abstraction face water conflicts between irrigation demand, drinkingwater supply and sustainable aquifer management (Macdonald et al. 1995; El-Naqa et al. 2007; Pavelic et al. 2012) - for example on the basaltic Deccan Traps in India, irrigation by groundwater has developed from shallow dug wells to mechanical abstraction since the 1950s. In the Maharashtra state in India alone, the total abstraction volume from more than 1.5 million wells has increased by over $700 \%$ since then (Macdonald et al. 1995).

One of the areas where severe groundwater depletion exists is the Moscow-Pullman region on the border of Idaho and Washington State in the USA (Fig. 1). Here, groundwater decline started with exploitation of upper aquifers in the early 20th century (Laney et al. 1923). The Moscow sub-basin is part of the Palouse basin, which is located on the eastern part of the Columbia River Basalt Group (CRBG; Hooper 1982). The CRBG aquifer is a main source of fresh water in the area (Tolan et al. 1989). Despite curtailed groundwater pumping since 1992, aquifer levels have continued to decline at 40 $60 \mathrm{~cm}$ year $^{-1}$ (Robischon 2006, 2007). The Moscow subbasin boundary is characterized by eolian loess deposits overlying eastward-dipping basalts to the west with granitic highlands and Miocene/Pliocene sediments to the east. These unique geologic zones interfinger in the subsurface (Fig. 2). Groundwater levels in the shallow basaltic aquifer (Wanapum Formation) recover in response to reduced pumping, indicating that recharge occurs to the shallow aquifer (Leek 2006). The presence of tritium in water samples recently taken from the Wanapum Formation and in some wells in the upper portion of the deeper basaltic aquifer (Grande Ronde), suggest that both these aquifers received recharge to some extent over the last 50 years (Carey 2011).

Identifying groundwater-recharge-source areas is critical to local managers and municipalities for targeting management which preserves and potentially enhances aquifer recharge. Previous work suggested that no vertical recharge occurs in the Moscow sub-basin (arrow A in Fig. 2). This was concluded based on the presence of thick impermeable clay deposits (up to $30 \mathrm{~m}$ ) that were identified through deep well logs (Lum et al. 1990; Bush 2005; Fairley et al. 2006). Rather than vertical percolation, lateral saturated flow occurs on top of these impermeable clays (Brooks et al. 2004). Using a spatially distributed hydrologic analysis approach, Dijksma et al. (2011) showed that it is possible that recharge occurs only in certain regions. They, and Bush (2005), suggested that the greatest potential for recharge might be via spatially discrete areas of high permeability (e.g. paleo-channels) draining from forested regions on the Moscow Mountain range front, recharging upper and lower aquifers at the granite/basalt interface (arrow B and C in Fig. 2). In addition, Dijksma et al. (2011) and Fairley et al. (2006) found evidence in boreholes of the existence of thick layers of coarse material, of which some end up at the surface as perennial springs (De Graaf 2011). Using a numeric groundwater model, De Graaf (2011) confirmed that aquifer recharge through paleochannels could provide a relatively large part of the aquifer recharge that occurs in the Paradise Creek watershed. It is very likely that paleo-channels are present and provide lateral conduits of groundwater recharge to the deeper aquifers (Brooks and Grader 2011). One of the remaining challenges is the identification of these groundwater recharge source areas in order to use these lateral conduits in MAR applications.

The aim of this study is to identify these groundwater recharge pathways in the Moscow sub-basin. A soil moisture routing (SMR) model (Dijksma et al. 2011) was used first, to provide a spatial representation of percolation below the root zone across the entire basin. Secondly, stable isotopes $\delta^{18} \mathrm{O}$ and $\delta^{2} \mathrm{H}$ as well as deuterium excess ( $d$-excess) were used to identify linkages between the surface water and groundwater systems. $\delta^{18} \mathrm{O}$ and $\delta^{2} \mathrm{H}$ have widely been recognized as useful tracers in providing insights into water movements in watersheds (McDonnell and Kendall 1992; Kendall and MacDonnell 1998). Seasonal and event-based variability in $\delta^{18} \mathrm{O}$ and $\delta^{2} \mathrm{H}$ in rain and snowmelt provide a unique composition which can be traced in streamflow and observed in groundwater wells. $\delta^{18} \mathrm{O}$ and $\delta^{2} \mathrm{H}$ tracers have been used in the Moscow sub-basin to describe variability in groundwater sources; however, since only one sample was taken from each well at different moments in time (Larson et al. 2000; Carey 2011; Moxley 2012) these studies were not able to investigate temporal variability in $\delta^{18} \mathrm{O}$ and $\delta^{2} \mathrm{H}$. If a hydrologic connection exists between two different sources of water (e.g. groundwater, precipitation or surface water), then it is expected that the down-gradient water source would have a similar but damped $\delta^{18} \mathrm{O}$ and $\delta^{2} \mathrm{H}$ that is lagged in time relative to upgradient sources (Changnon 1987; Soulsby and Tetzlaff 2008; Katsuyama et al. 2010; Speed et al. 2010; Wassenaar et al. 2011). If a hydrologic connection between different sources of water exists, temporal fluctuations in $\delta^{18} \mathrm{O}$ and $\delta^{2} \mathrm{H}$ will be hydrologically similar (Scanlon et al. 2002).

In addition to $\delta^{18} \mathrm{O}$ fluctuations, the $\delta^{18} \mathrm{O}$ can be compared to the Global Meteoric Water Line (GMWL: $\delta^{2} \mathrm{H}=$ $\left.8 \times \delta^{18} \mathrm{O}+10\right)$, that serves as a reference to determine deviations of the relation between $\delta^{18} \mathrm{O}$ and $\delta^{2} \mathrm{H}$ (Craig 1961). The offset of 10 is determined by kinetic isotope fractionation that occurs during non-equilibrium processes such as evaporation (Craig 1961; Cappa et al. 2003). This offset can be calculated by the $d$-excess $\left(d=\delta^{2} \mathrm{H}-8 \times \delta^{18} \mathrm{O}\right)$, and is a measure for the relative proportions of $\delta^{2} \mathrm{H}$ and $\delta^{18} \mathrm{O}$ that are affected by evaporation (Dansgaard 1964). The correlation with precipitation is higher when the $d$-excess of a water source is close to $10 \%$. A $d$-excess close to $10 \%$ also indicates that precipitation has 


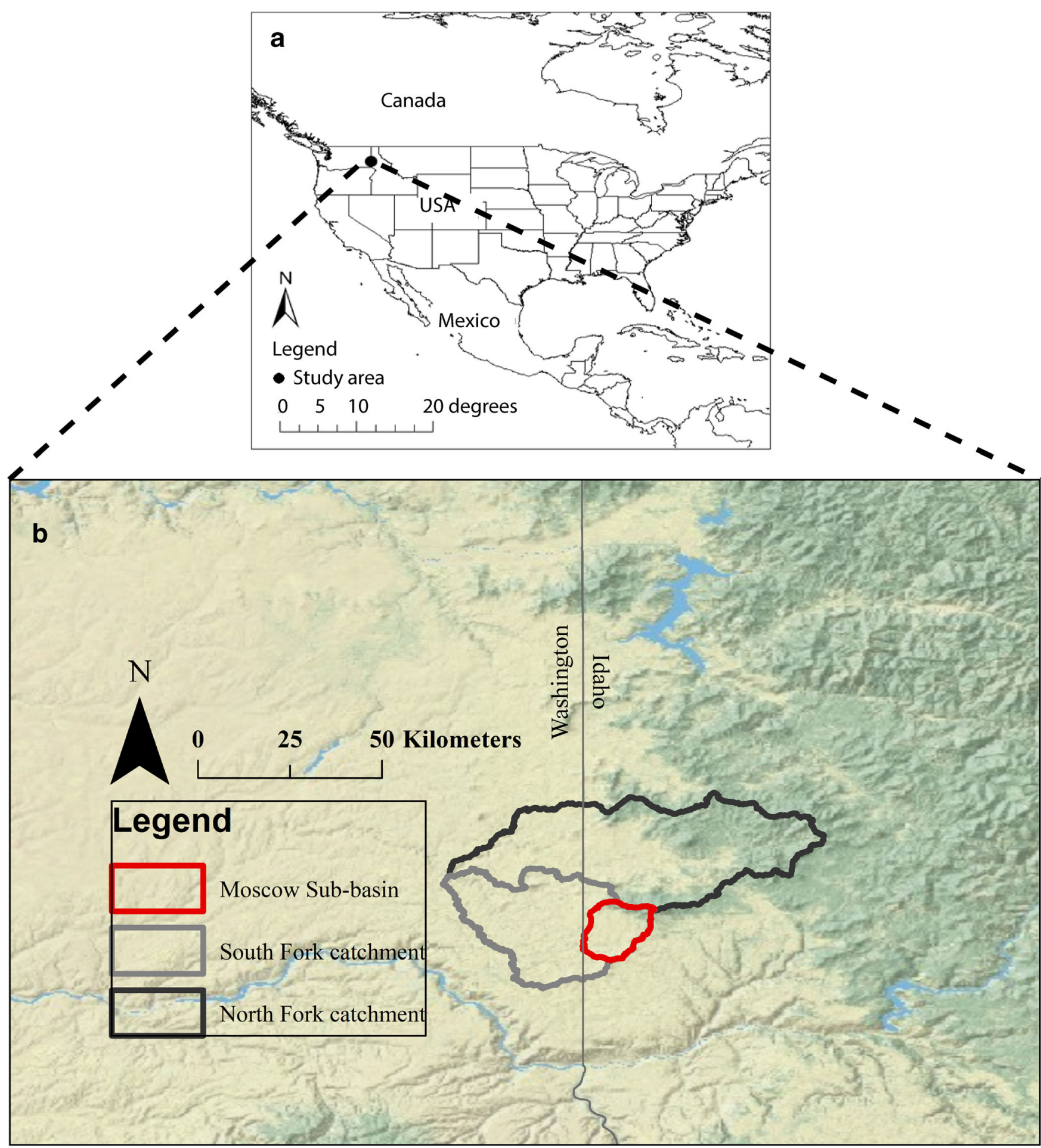

Fig. 1 a The Moscow sub-basin (study area), located in the Palouse Basin, on the border of Idaho/Washington state, USA. b The Palouse Basin, subdivided in the North Fork and South Fork of the Palouse
River. The red line shows the Moscow sub-basin Figures 1 and 3 contains poor quality of text. Otherwise, please provide replacement figure file.correct infiltrated and percolated below the root zone quickly, and has not been subject to evaporation (Froehlich et al. 2001). Sánchez-Murillo et al. (2015) measured $\delta^{18} \mathrm{O}$ and $\delta^{2} \mathrm{H}$ in precipitation $(N$ samples $=203)$ and streamflow $(N=244$ and
$N=195$, in Crumarine Creek and the South Fork of the Palouse River, respectively) from June 2011 to January 2014 (Fig. 3). Their record provides the isotopic baseline necessary to investigate hydrologic connections to groundwater. 
A

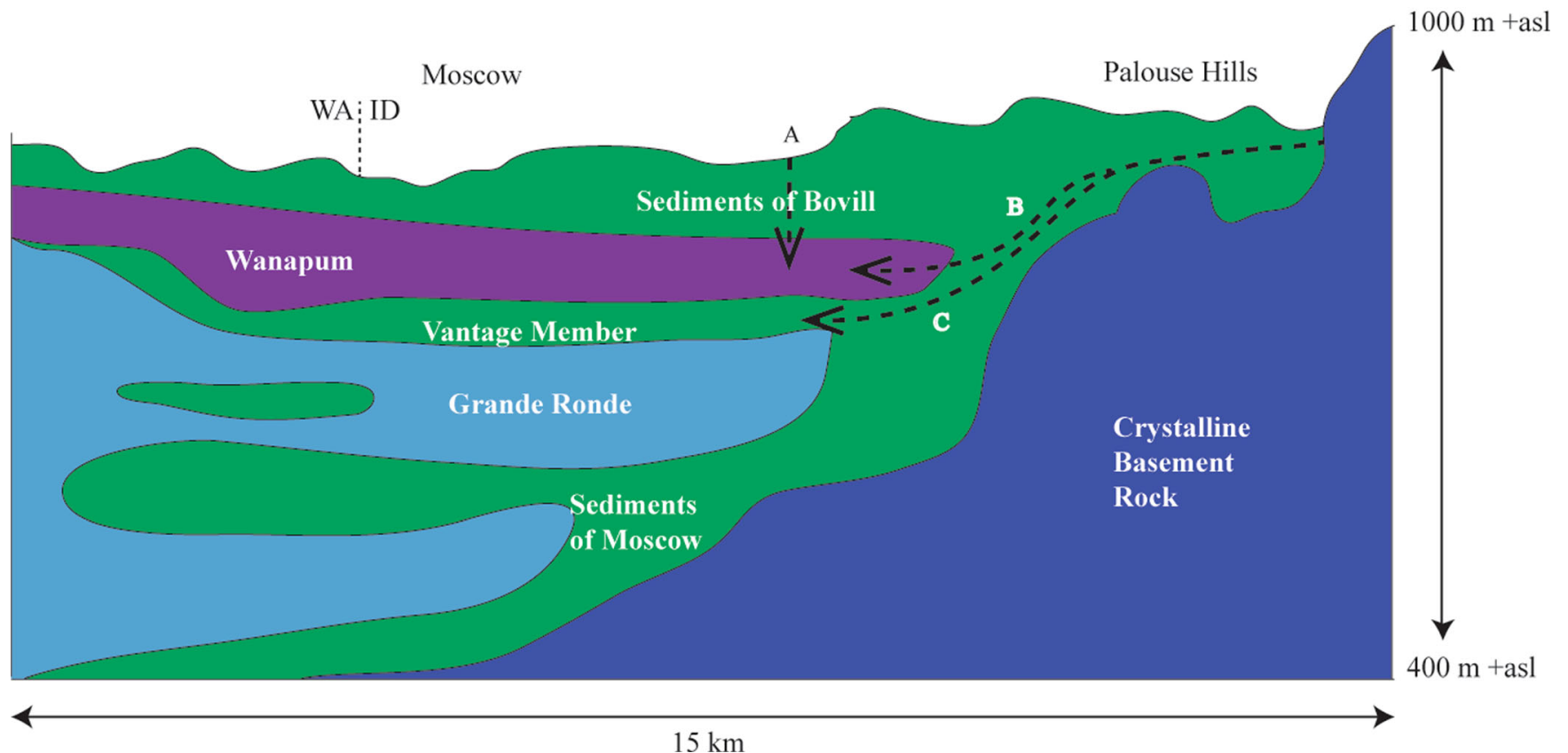

Fig. 2 Geological cross-section of the Moscow sub-basin (after Bush and Garwood 2005). Letters $A-C$ and dashed arrows correspond to the recharge pathways mentioned in the text. Cross-section is based on approximate $\mathrm{W}-\mathrm{E}$ dashed line $\mathrm{A}-\mathrm{A}^{\prime}$ in Fig. 4

\section{Area description}

Figure 4a shows the digital elevation model for the Moscow sub-basin, including the drainages from Moscow Mountain (part of the east-west trending Palouse Range). These drainages include Paradise Creek and the South Fork of the Palouse River. Discharge measurements by the US Geological Survey (USGS) of Paradise Creek near the University of Idaho Campus from 1979 to 2012 indicate the mean annual discharge of $0.12 \mathrm{~mm} /$ year. The South Fork of the Palouse River at Pullman (Washington) has a mean annual discharge of $0.40 \mathrm{~mm} /$ year, which includes the Paradise Creek discharge (US Geological Survey 2012). Non-irrigated agriculture is the dominant land use in the Moscow sub-basin (71 \%); forest (15\%), grass fields $(6 \%)$, and urban areas $(8 \%)$ are the other land use types present (Fig. 4b; Bara and Shaw 1995).

Pullman-Moscow groundwater systems are fairly complex with multiple basalt flows underlain by and laterally resting against protruding basement metamorphic/granitic ridges. Basin margin paleo-valleys occur at different scales, and are stacked and altered through geologic time by successive basalt dam effects and are interwoven with clay and sand/gravel lacustrine and stream/ swamp inter-beds (Grader 2011). High-porosity interbeds (associated with subordinate paleochannels) are known to occur at lower stratigraphic levels (Grader 2011).

Fig. 3 Local meteoric water lines for various water sources collected in this study in comparison to the global meteoric water line (GMWL). Crumarine Creek and precipitation is according to Sánchez-Murillo et al. 2015

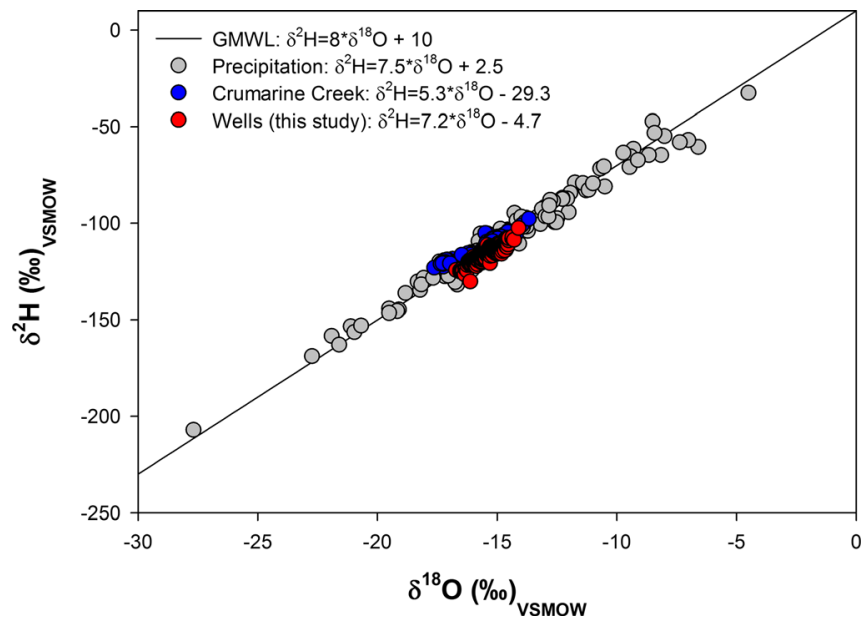




\section{a}

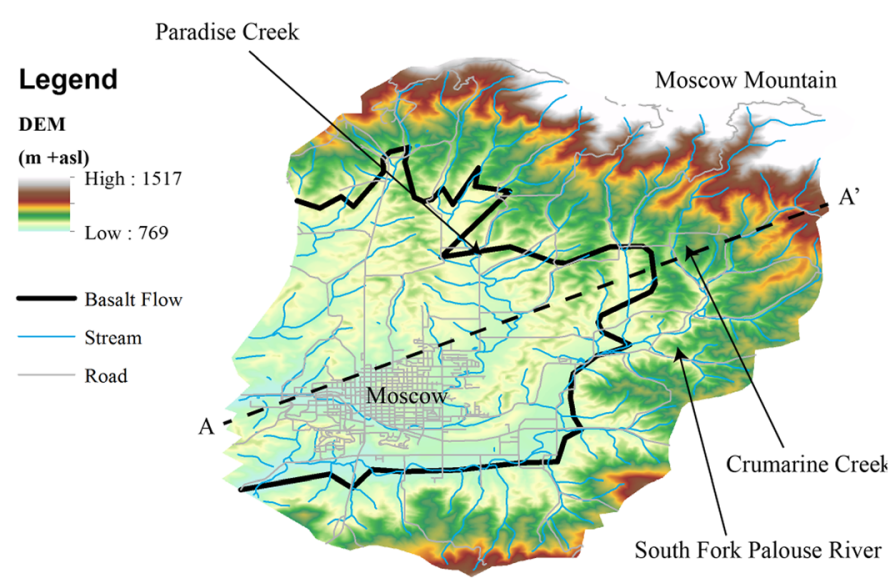

b

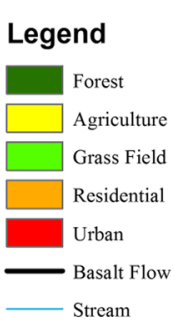

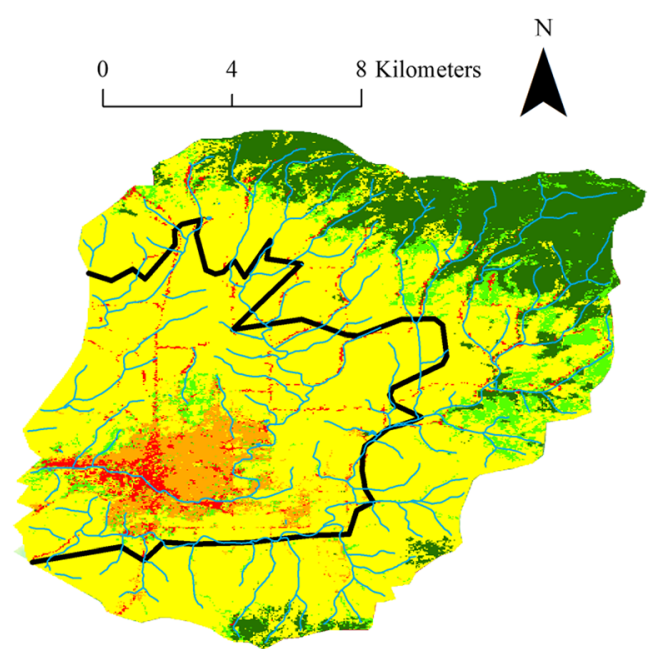

Fig. 4 a Digital elevation model (DEM) of the Moscow sub-basin. Black line indicates the extent of the CRBG basalt flows, defined by Grader (2011). The dashed line $\mathrm{A}-\mathrm{A}^{\prime}$ represents the geological cross-section as shown in Fig. 2, b Land use map of the Moscow sub-basin

The extent of the upper CRBG basalt flows (Wanapum Basalt) is indicated in Fig. 4. Underlying older, thicker Grande Ronde flows occur westward of this transitional line (shown in cross-section, Fig. 2). Associated aquifers use the same names "upper Wanapum" or "lower Grande Ronde" formations, but involve heterogeneous geology. The CRBG basalt flows are inter-fingered with Miocene and younger sediments (Latah Formation including Sediments of Moscow, Vantage Member, and Sediments of Bovill), and are a result of alluvial deposition when basalt flows blocked former drainage patterns (Fig. 2). A detailed Quaternary surficial geological map is dominated by eolian deposited loess silts (Palouse Formation) as shown in Fig. 5. Arable stoneless soils show that no ice age tillites were deposited at this latitude; however, major volcanic airfall ashes derived from the Cascade Mountains were admixed into both Miocene and Quaternary sediments. Lower through upper Miocene sediments are a mixture of all textures from clay to sand and gravel (Lum et al. 1990; Bush 2005; Fairley et al. 2006). This research focuses on recharge in this part of the basin, where paleo-channels of different orders of size should be contained by and will laterally migrate within the larger-scaled subsurface paleo-valleys.

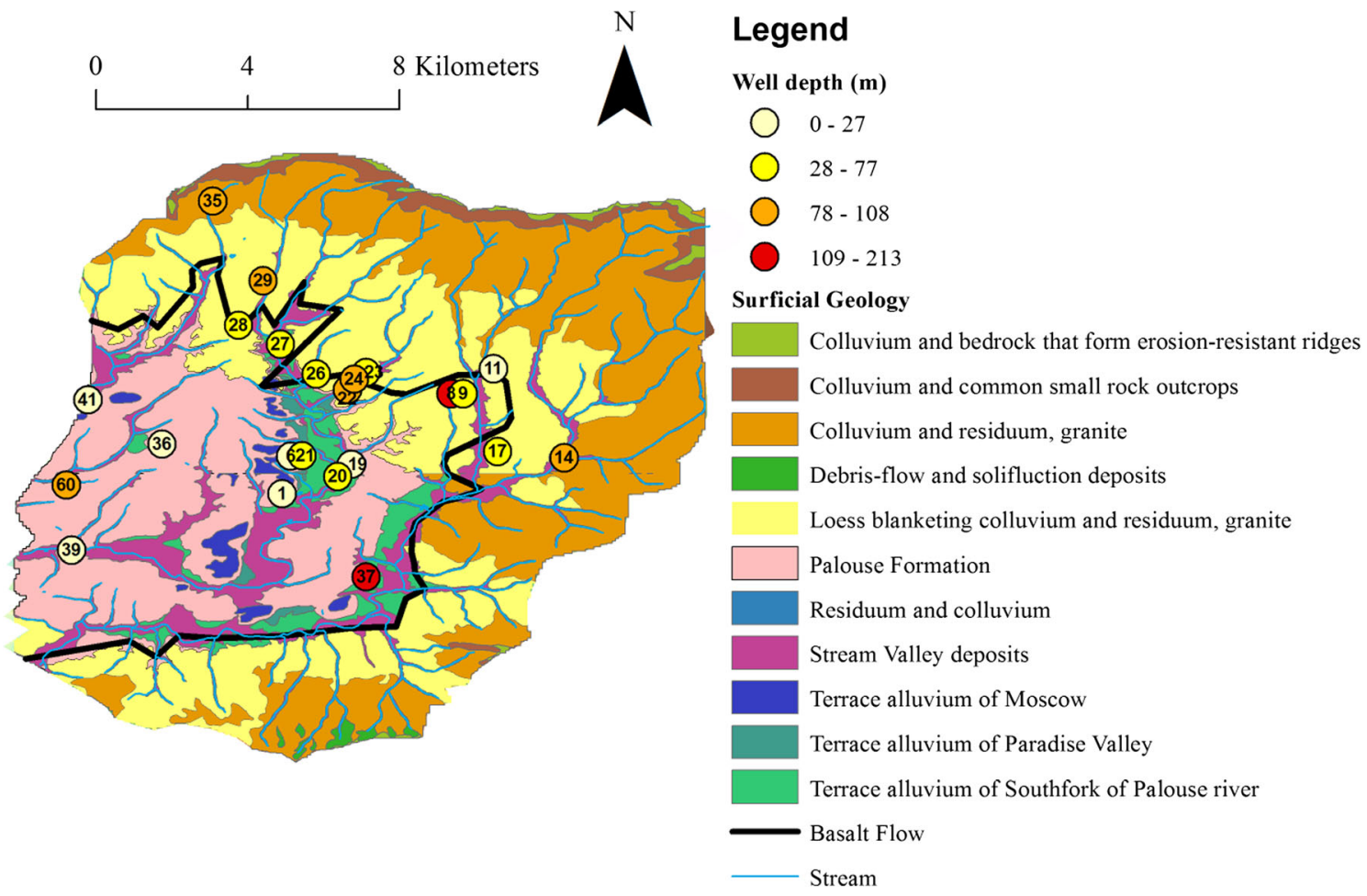

Fig. 5 Surficial geological map of the Moscow sub-basin including the well locations, well sample IDs (1-60) and well depth (Othberg et al. 2001) 
The Wanapum and Grande Ronde aquifers are deformed, and tectonic features or feeder dikes may be present resulting in isolated groundwater reservoirs with low connectivity (McVay 2007). Locally open horizontal and vertical fractures are present and are, at present, clay- or even sand-filled. These fractures have not been extensively studied and are likely to vary spatially (Fairley et al. 2006). Unpredictable rock/ sediment relationships are the result of invasive basalts that flowed over wet sediments as observed in ancient lakes or fluvial streams along paleo-valley boundaries. Previous attempts to predict groundwater flow in the Wanapum and Grande Ronde aquifers by numerical modelling (Barker 1979; Lum et al. 1990; Hansen et al. 1994; Whiteman et al. 1994; Vaccaro 1999; Reidel et al. 2003) were often inconsistent due to the combination of both aquifer's hydrogeological heterogeneity and the complex groundwater extractions from different locations and intervals (Leek 2006; McVay 2007; Bennett 2009).

\section{Material and methods}

In this study, the hydrologic connections between precipitation, streamflow, and groundwater are investigated by testing groundwater in 22 wells and 2 springs throughout the Moscow sub-basin (Fig. 5; Table 1). These locations have been selected based on a preliminary sampling of 49 wells and 3 springs (Candel 2014). Well information was derived from the online database of the Idaho Department of Water Resources (IDWR; Idaho Department of Water Resources 2013). When well information was not present in the online database, it was derived from the well owners. Each of the wells and springs were sampled once every 2 weeks. In total, 352 samples have been analysed for $\delta^{18} \mathrm{O}$ and $\delta^{2} \mathrm{H}$. Wells were selected based on geology, well depth (Fig. 4b), and proximity to streams, with the intention to have distributed samples throughout the Moscow sub-basin (Idaho Department of Water Resources 2013). Water samples are

Table 1 Characteristics of all wells and springs that were sampled

\begin{tabular}{|c|c|c|c|c|c|c|c|c|c|}
\hline \multirow{2}{*}{$\begin{array}{l}\text { Well sample } \\
\text { ID }\end{array}$} & \multirow[t]{2}{*}{ Well ID } & \multirow[t]{2}{*}{ Bedrock } & \multicolumn{2}{|c|}{ Depth } & \multicolumn{3}{|l|}{ Elevation } & \multirow[t]{2}{*}{ Long } & \multirow[t]{2}{*}{ Lat } \\
\hline & & & $\begin{array}{l}\text { Well } \\
(\mathrm{m})\end{array}$ & $\begin{array}{l}\text { Water } \\
(\mathrm{m})\end{array}$ & $\begin{array}{l}\text { Well top } \\
(\mathrm{m}+\text { asl })\end{array}$ & $\begin{array}{l}\text { Well } \\
\text { bottom } \\
(\mathrm{m}+\mathrm{asl})\end{array}$ & $\begin{array}{l}\text { Water } \\
\text { level } \\
(\mathrm{m}+\mathrm{asl})\end{array}$ & & \\
\hline 1 & 279844 & SOB & 24 & 20 & 812 & 788 & 792 & -116.975467 & 46.745203 \\
\hline 5 & 279433 & B & 72 & 53 & 818 & 746 & 765 & -116.973363 & 46.754049 \\
\hline 6 & Spring & - & 0 & - & 818 & 818 & - & -116.973363 & 46.754049 \\
\hline 8 & 411379 & $\mathrm{G}$ & 213 & 184 & 842 & 628 & 658 & -116.935307 & 46.768930 \\
\hline 9 & 279954 & SOB & 77 & 74 & 832 & 755 & 758 & -116.932524 & 46.768905 \\
\hline 11 & 279918 & G & 27 & 24 & 849 & 821 & 825 & -116.925279 & 46.774895 \\
\hline 14 & - & - & 102 & - & 823 & 721 & - & -116.908495 & 46.753806 \\
\hline 17 & 280306 & G & 43 & 37 & 829 & 786 & 792 & -116.924215 & 46.755273 \\
\hline 19 & Spring & - & 0 & - & 809 & 809 & - & -116.958980 & 46.752131 \\
\hline 20 & 279727 & B & 55 & 44 & 800 & 745 & 756 & -116.962160 & 46.749262 \\
\hline 21 & 279905 & SOB & 46 & 22 & 811 & 765 & 789 & -116.970663 & 46.754251 \\
\hline 22 & $\begin{array}{c}280057 \text { and } \\
280008\end{array}$ & SOB & 105 & 42 & 817 & 712 & 775 & -116.959883 & 46.769872 \\
\hline 23 & 280053 & SOB & 62 & 13 & 827 & 765 & 814 & -116.955420 & 46.773923 \\
\hline 24 & 338130 & SOB & 93 & 84 & 832 & 739 & 748 & -116.958287 & 46.772420 \\
\hline 26 & 279678 & $\mathrm{~B}$ & 47 & 42 & 817 & 771 & 775 & -116.967314 & 46.773636 \\
\hline 27 & 389781 & G & 67 & 53 & 824 & 757 & 772 & -116.975827 & 46.780564 \\
\hline 28 & 279492 & SOB & 73 & 71 & 834 & 762 & 763 & -116.985709 & 46.785009 \\
\hline 29 & 279708 & G & 93 & 83 & 839 & 746 & 756 & -116.979895 & 46.795657 \\
\hline 35 & - & G & 94 & 5 & 950 & 857 & 945 & -116.991942 & 46.814497 \\
\hline 36 & 280524 & SOB & 19 & 14 & 815 & 796 & 801 & -117.003918 & 46.756973 \\
\hline 37 & - & $\mathrm{B}$ & 150 & 32 & 797 & 647 & 765 & -116.955450 & 46.725566 \\
\hline 39 & - & B & 21 & 20 & 774 & 753 & 755 & -117.025350 & 46.731821 \\
\hline 41 & - & B & 27 & 27 & 798 & 770 & 771 & -117.021437 & 46.767460 \\
\hline 60 & - & $\mathrm{V}$ & 108 & 107 & 800 & 692 & 693 & -117.026589 & 46.747202 \\
\hline
\end{tabular}

The bedrock codes are defined as: $S O B$ Sediments of Bovill, $B$ basalt, $G$ granite, $V$ Vantage Member 
taken directly from outdoor spigots after flushing the system of old water. Water lines were flushed until the water temperature was constant. Water samples were collected in 30-ml glass E-C borosilicate bottles with TFE-lined caps (Wheaton Science Products, USA) and stored upside down at $5{ }^{\circ} \mathrm{C}$. Bottles were filled with no head space and covered with parafilm (Thermo Scientific, USA) to avoid exchange with atmospheric moisture.

Stable isotope analyses were conducted at the Idaho Stable Isotope Laboratory, University of Idaho (Idaho, USA) using a cavity ring-down spectroscopy (CRDS) water isotope analyser L1120-i (Picarro, USA). Laboratory standards, previously calibrated to the reference waters Vienna Standard Mean Ocean Water and Standard Light Antarctic Precipitation (VSMOW2SLAP2), were glacier water $\left(\delta^{2} \mathrm{H}=-255.0 \%\right.$, $\delta^{18} \mathrm{O}=-30.8$ $\%$ ), commercial bottled water $\left(\delta^{2} \mathrm{H}=-64.2 \%\right.$, $\delta^{18} \mathrm{O}=-8.3$ $\%$ ), and Moscow tap water $\left(\delta^{2} \mathrm{H}=-125.5 \%\right.$, $\delta^{18} \mathrm{O}=-15.4$ $\%$ ). Glacier water and commercial bottled water were used to normalize the results to the VSMOW2-SLAP2 scale, while the Moscow tap water was a quality control standard. The laboratory instrument precision on average was $\pm 0.5 \%$ o $(1 \sigma)$ for $\delta^{2} \mathrm{H}$ and $\pm 0.1 \%$ o $(1 \sigma)$ for $\delta^{18} \mathrm{O}$. The estimated $d$-excess analytical uncertainty was $\pm 0.6 \%$ ( $1 \sigma)$.

A check to the suitability of using outdoor spigots was completed by quantifying changes in $\delta^{18} \mathrm{O}$ with time at five spigots. The temporal variation in $\delta^{18} \mathrm{O}$ after 2,5 and $10 \mathrm{~min}$ of flushing was always smaller than the standard error of the Picarro Instrument, indicating that differences found in isotopic composition cannot be explained by different water being sampled within the pipelines of the wells.

\section{Soil-moisture routing model}

In this study, a SMR model was used to provide spatial predictions of the mean annual percolation rates below the root zone throughout the Moscow sub-basin. The SMR model used is a spatially distributed, grid-based hydrologic model which operates within a geographic information system (GIS) environment, originally developed at Cornell University (Frankenberger et al. 1999). The model simulated interception, evapotranspiration, subsurface lateral flow, deep vertical percolation and saturation-excess surface runoff through a multi-layer soil profile. Snow accumulation and melt is simulated using an energy balance approach (Brooks and Boll 2005; Brooks et al. 2007). The SMR model has been developed as a spatially explicit management tool and therefore has been developed to rely primarily on publicly available data with minimal calibration (Frankenberger et al. 1999; Brooks et al. 2007). It uses spatial explicit topographic, land cover, and soil maps to represent the hydrologic mass balance within the root zone of a watershed. It is particularly well suited in landscapes having restrictive soil horizons (e.g. argillic and fragipan) where saturation excess runoff is generated by the subsurface lateral redistribution of water following variable source area hydrology concepts (Brooks et al. 2004, 2007; McDaniel et al. 2008). Despite the modest input requirements, modelling results are at least as good as more complex hydrology models (Johnson et al. 2003; Mehta et al. 2004; Dijksma et al. 2011). Brooks et al. (2007) demonstrated the ability of the model to accurately represent the development of shallow, dynamic perched water tables over restrictive fragipan soil horizons, including snow accumulation and melt, and surface runoff, from a small grassland catchment on the eastern edge of the Moscow sub-basin.

Dijksma et al. (2011) applied and assessed the ability of the SMR model to represent the hydrology of the Paradise Creek watershed. The Paradise Creek watershed is also located in the Moscow sub-basin (Fig. 2), and covers approximately one third of the total $\left(150 \mathrm{~km}^{2}\right)$ area. The Nash-Sutcliffe efficiency (NSE; Nash and Suthcliffe 1970) between observed and simulated streamflow from Paradise creek watershed was 0.57, which is a "good" result according to the qualitative assessment of NSE by Foglia et al. (2009). More details can be found in Dijksma et al. (2011).

Since the focus of this study was on the entire Moscow subbasin, the spatial extent of the Dijksma et al. (2011) model extended to cover the entire region. The model was extended using the same topographic, land cover, soil maps and parameters as had been used as by Dijksma et al. (2011). The daily average percolation was calculated by SMR for each $30 \times 30 \mathrm{~m}$ cell in the Moscow sub-basin, over the period 2001-2008.

\section{Results}

\section{Model}

As seen in Fig. 6, the SMR model indicates that percolation rates vary spatially with the greatest average percolation rate of $2 \mathrm{~mm} \mathrm{~d}^{-1}$, whereas there are other areas that have negligible percolation. The overall average daily percolation over the Moscow sub-basin was $0.50 \mathrm{~mm} \mathrm{~d}^{-1}$.

\section{Isotopes}

Table 2 shows the results of the $\delta^{18} \mathrm{O}$ analysis for all wells and springs. The $\delta^{18} \mathrm{O}$ values for the wells varied from $-16.7 \%$ in well 23 to $-14.1 \%$ in well 39. The temporal fluctuations in $\delta^{18} \mathrm{O}$ varied in magnitude at each of the sampled wells and springs. The variability in $\delta^{18} \mathrm{O}$ was significant and consistent across many of the locations. Figure 7 a shows highly dynamic $\delta^{18} \mathrm{O}$ fluctuations at four wells that had the highest standard deviation in $\delta^{18} \mathrm{O}$ (wells 9, 14, 24 and 27). In contrast, $\delta^{18} \mathrm{O}$ in some other wells is relatively stable. Figure $7 \mathrm{~b}$ shows relatively stable $\delta^{18} \mathrm{O}$ fluctuations at four wells that had the lowest standard deviation in $\delta^{18} \mathrm{O}$ (wells $11,35,36,37$ ). The standard deviation correlates with the maximum range in $\delta^{18} \mathrm{O}$ values $\left(R^{2}=0.91\right)$. Figure $8 \mathrm{~b}$ 
Fig. 6 Daily average percolation in the Moscow sub-basin in $\mathrm{m}$ $\mathrm{d}^{-1}$. A result from the SMR model

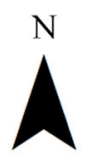

Legend

Mean percolation rate $\left(\mathrm{mm} \mathrm{d}^{-1}\right)$

$=\begin{aligned} & \text { High : } 2 \\ & \text { Low : } 0\end{aligned}$

Basalt Flow

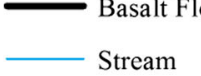

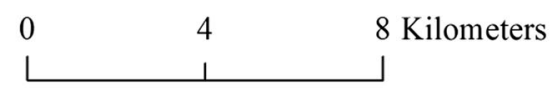

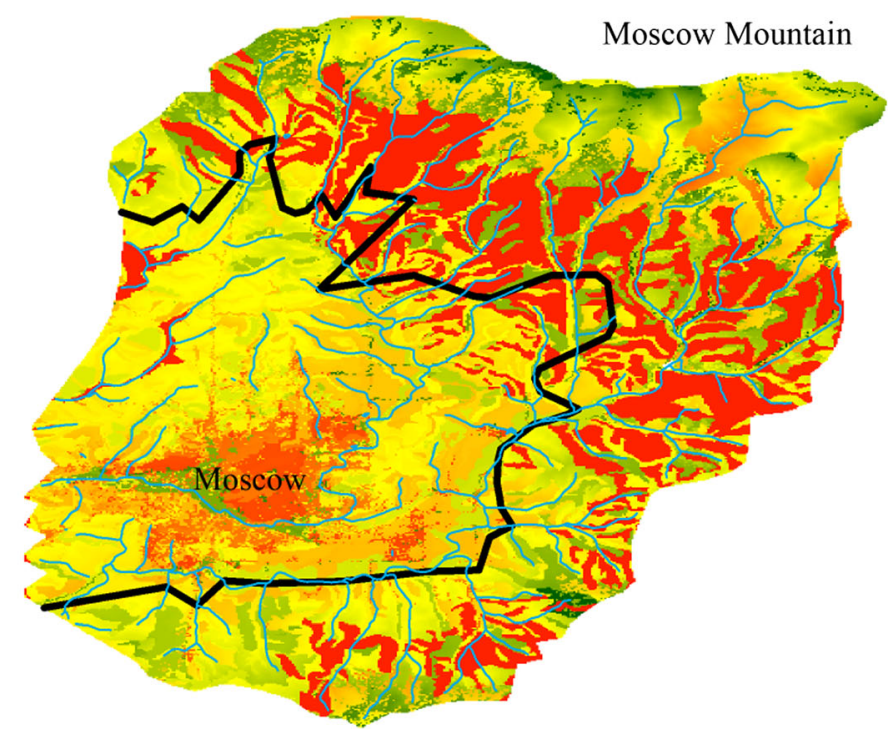

Table 2 Results of water samples from all wells and springs, from 17-04-2013 until 02-01-2014. SD standard deviation

\begin{tabular}{|c|c|c|c|c|c|c|c|}
\hline \multirow[t]{2}{*}{ Well sample ID } & \multicolumn{3}{|c|}{$\partial^{18} \mathrm{O}$ ratio } & \multirow{2}{*}{$\begin{array}{l}d \text {-excess } \\
(\% \circ)\end{array}$} & \multirow{2}{*}{$\begin{array}{l}\text { Mean temp. } \\
\left({ }^{\circ} \mathrm{C}\right)\end{array}$} & \multirow{2}{*}{$\begin{array}{l}\text { Mean EC } \\
\left(\mu \mathrm{S} \mathrm{cm}^{-1}\right)\end{array}$} & \multirow[t]{2}{*}{$n$} \\
\hline & $\begin{array}{l}\text { Mean } \\
(\% o)\end{array}$ & $\begin{array}{l}\text { SD } \\
(\% \circ)\end{array}$ & $\begin{array}{l}\text { Range } \\
(\% \circ)\end{array}$ & & & & \\
\hline 1 & -15.24 & 0.13 & 0.47 & 7.0 & 11.4 & 227 & 18 \\
\hline 5 & -16.05 & 0.11 & 0.87 & 7.4 & 11.6 & 282 & 19 \\
\hline 6 & -14.53 & 0.10 & 1.64 & 8.0 & 12.7 & 287 & 14 \\
\hline 8 & -15.89 & 0.20 & 0.67 & 7.8 & 12.3 & 249 & 19 \\
\hline 9 & -15.76 & 0.30 & 1.20 & 7.8 & 13.9 & 227 & 19 \\
\hline 11 & -15.37 & 0.10 & 0.54 & 8.2 & 11.0 & 172 & 17 \\
\hline 14 & -15.40 & 0.28 & 1.05 & 8.5 & 12.8 & 457 & 18 \\
\hline 17 & -15.39 & 0.10 & 0.37 & 8.4 & 15.1 & 126 & 14 \\
\hline 19 & -15.10 & 0.18 & 0.66 & 7.6 & 12.8 & 211 & 20 \\
\hline 20 & -15.64 & 0.10 & 0.43 & 8.0 & 13.4 & 278 & 17 \\
\hline 21 & -15.01 & 0.16 & 0.63 & 6.9 & 11.7 & 389 & 18 \\
\hline 22 & -15.80 & 0.13 & 0.50 & 7.5 & 14.2 & 241 & 18 \\
\hline 23 & -16.46 & 0.12 & 0.46 & 7.0 & 16.1 & 326 & 13 \\
\hline 24 & -15.34 & 0.25 & 0.80 & 7.4 & 14.0 & 220 & 18 \\
\hline 26 & -15.45 & 0.19 & 0.76 & 7.9 & 13.6 & 215 & 17 \\
\hline 27 & -15.10 & 0.22 & 0.56 & 7.4 & 11.8 & 222 & 18 \\
\hline 28 & -15.43 & 0.10 & 0.42 & 8.3 & 12.1 & 201 & 18 \\
\hline 29 & -15.55 & 0.22 & 0.63 & 8.1 & 11.9 & 377 & 18 \\
\hline 35 & -15.20 & 0.10 & 0.55 & 9.1 & 11.9 & 262 & 17 \\
\hline 36 & -14.90 & 0.10 & 0.41 & 7.4 & 13.6 & 430 & 18 \\
\hline 37 & -16.14 & 0.07 & 0.44 & 8.8 & 14.1 & 257 & 19 \\
\hline 39 & -14.89 & 0.26 & 0.96 & 6.4 & 13.7 & 607 & 17 \\
\hline 41 & -15.15 & 0.12 & 0.44 & 7.7 & 11.7 & 256 & 17 \\
\hline 60 & -14.15 & 1.12 & 0.34 & -6.9 & 10.9 & 268 & 5 \\
\hline
\end{tabular}


Fig. 7 a $\delta^{18} \mathrm{O}$ readings for the four most dynamic wells in the study, including the precipitation $\delta^{18} \mathrm{O}, \mathbf{b} \delta^{18} \mathrm{O}$ readings for the four most stable wells in the study, including the precipitation $\delta^{18} \mathrm{O}$

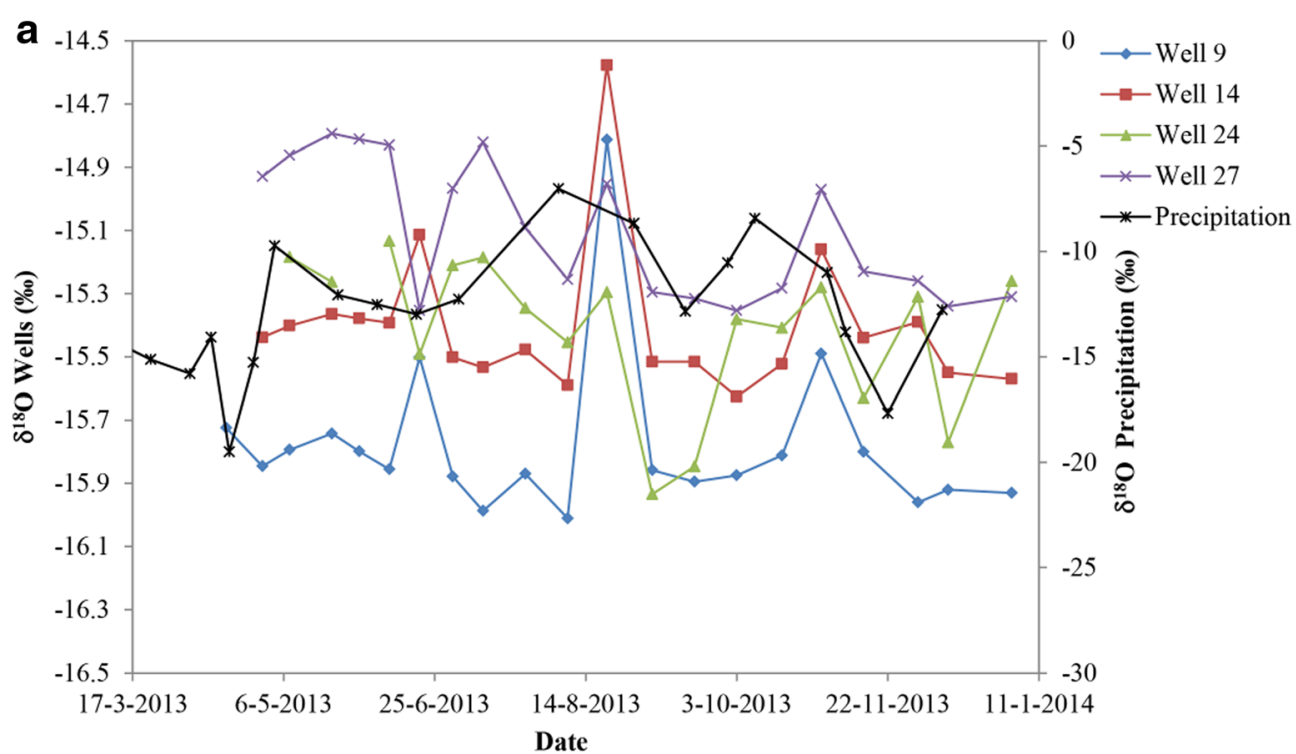

\section{b}

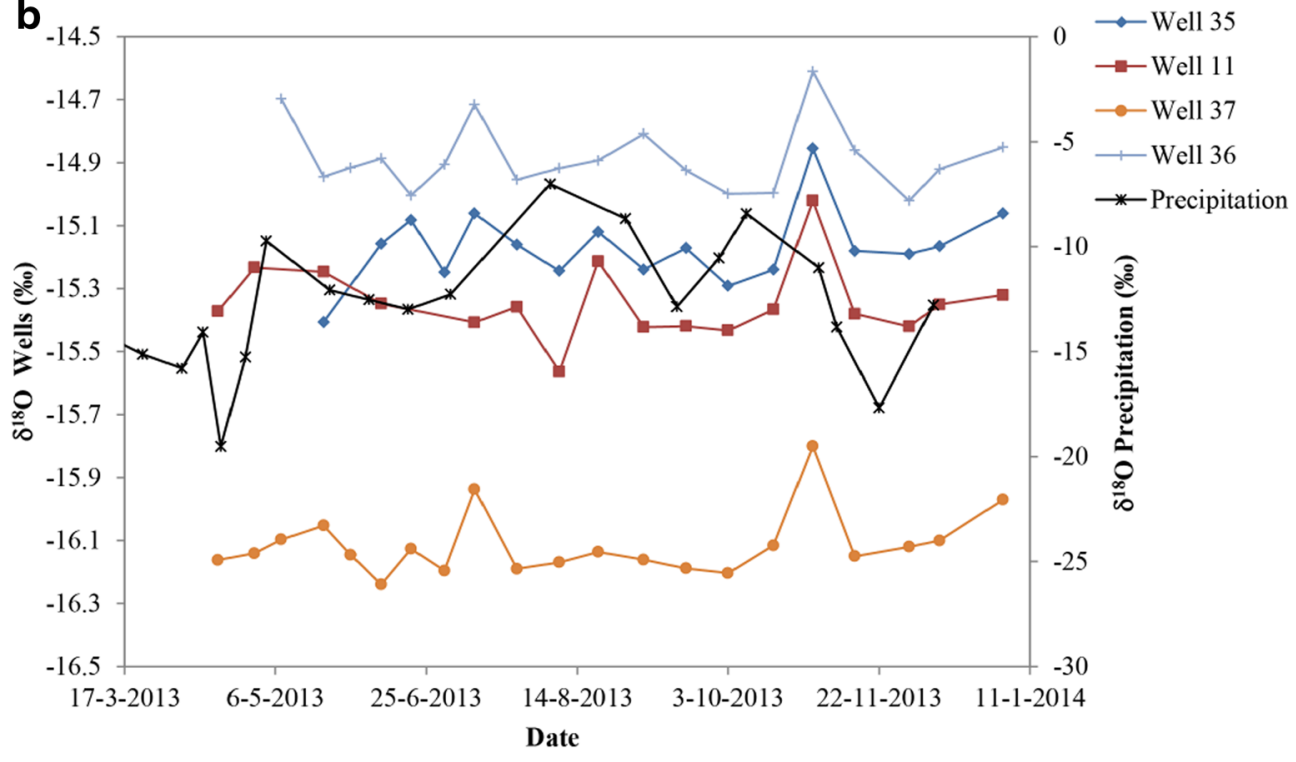

shows the spatial distribution of the maximum range in $\delta^{18} \mathrm{O}$ in all wells and springs. Similarly, Fig. 8c shows the spatial distribution of the average $d$-excess in all wells and springs. Interestingly the fluctuations in $\delta^{18} \mathrm{O}$ indicated by Fig. $8 \mathrm{~b}$, c do not necessarily correlate with well depth (Fig. 8a). For example, deep wells (e.g. wells $35,29,9,14$ ) can have high fluctuations in $\delta^{18} \mathrm{O}$ and a high $d$-excess and shallow wells can have stable fluctuations and a low $d$-excess (e.g. wells 1, 41, 36).

\section{Discussion}

\section{Recharge in the Moscow sub-basin}

According to the SMR model, most of the percolation occurs at higher elevations near Moscow Mountain. The relatively large percolation at the higher elevations can be partially attributed to the fact that Moscow Mountain receives nearly twice the precipitation $(1,270 \mathrm{~mm})$ as the city of Moscow located at relatively low elevation in the study area (WRCC 2013). The model predicts zero percolation in areas having strong hydraulically restrictive argillic soil characteristics. Instead of water moving vertically through these horizons, perched water tables develop in these soils and the water then will run laterally downslope, producing runoff at toe-slope positions. Soils having low percolation exist throughout a large part of the eastern Palouse region between Moscow and the Moscow Mountain, where thick clay layers are present (Lum et al. 1990; Fairley et al. 2006; Dijksma et al. 2011). Percolation is also limited within the city of Moscow due to impervious surfaces which route water through storm drain networks.

The $\delta^{18} \mathrm{O}$ data indicate that connections exist between precipitation, surface water and groundwater. It is suggested here that there are two characteristics in the $\delta^{18} \mathrm{O}$ data that indicate 


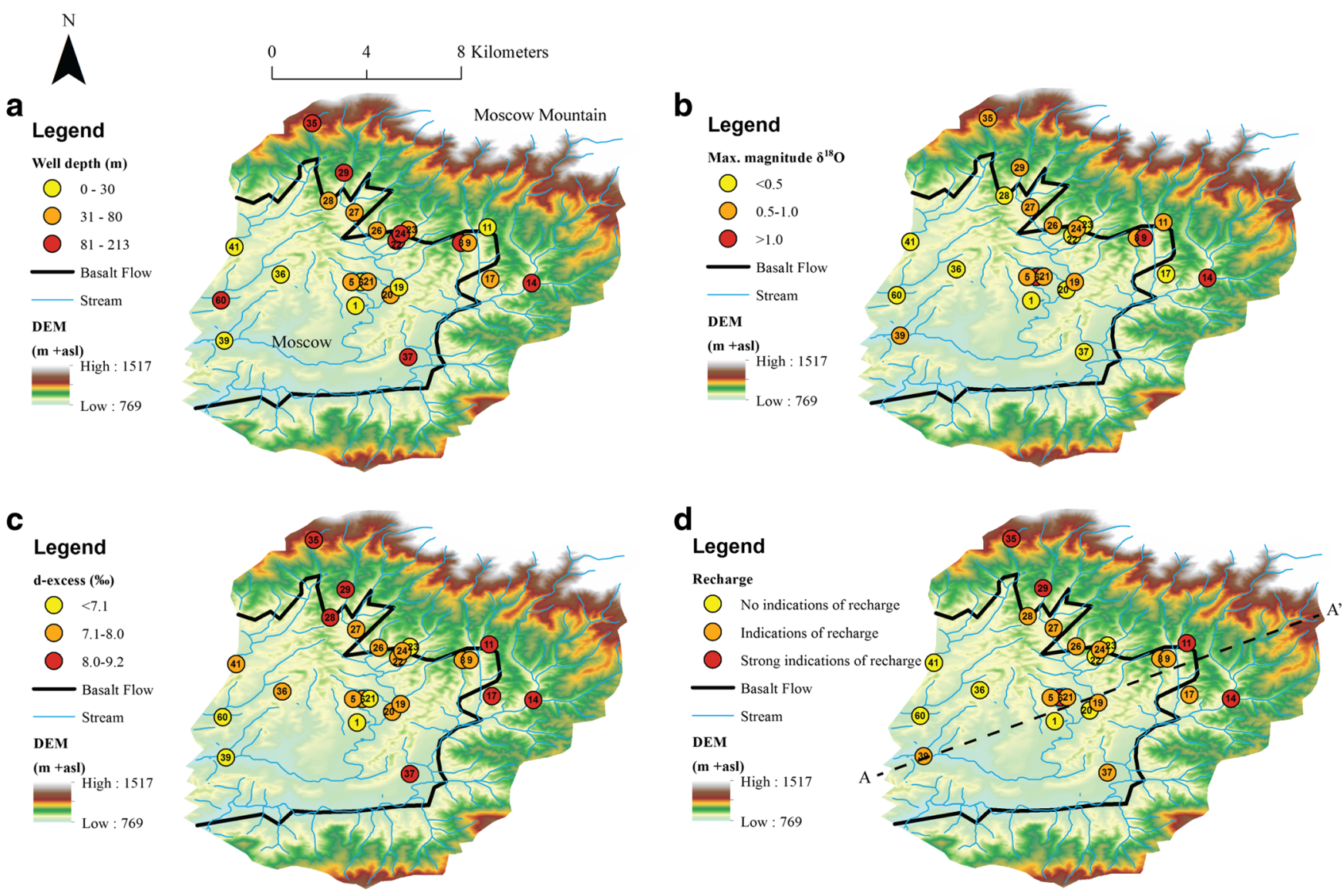

Fig. 8 Well locations plotted on the DEM. Numbers indicate the well sample IDs. a the depth of the wells, $\mathbf{b}$ the maximum magnitude of the $\delta^{18} \mathrm{O}$ composition, $\mathbf{c}$ the average $d$-excess for all samples, $\mathbf{d}$ indications of recharge

recharge. Firstly, the magnitude of $\delta^{18} \mathrm{O}$ fluctuations, whereby if fluctuations are large, then the groundwater is hydrologically connected to a source of water causing these variations in $\delta^{18} \mathrm{O}$. This different source can either be groundwater recharge from precipitation or surface water. As seen in Fig. 7, there is considerable overlap in the range of $\delta^{18} \mathrm{O}$ values in wells exhibiting both relatively large and small fluctuations, which suggests that no distinction in recharge can be made based on the average annual $\delta^{18} \mathrm{O}$; hence, the time record is needed for this distinction. Interestingly, wells that have small $\delta^{18} \mathrm{O}$ fluctuations still have a dampened $\delta^{18} \mathrm{O}$, suggesting a slower connection or smaller amount of recharge may be occurring in these wells. The second characteristic that suggests that recharge is occurring is if the $d$-excess is close to $10 \%$. If water percolation occurs rapidly without excessive evaporation, then the groundwater will have a $d$-excess close to $10 \%$.

In order to examine the spatial patterns in recharge, three ranges were defined for each of these recharge indicators varying from no indications of recharge to strong indications of recharge. These categories are shown in Fig. 8b, c with different colors. Yellow, orange and red represent that the indications for recharge are absent, present and strong, respectively. Each of these categories was given a value of 0 to 2 , respectively. Figure $8 d$ shows the sum of these values for both recharge indicators in similar categories ranging from yellow (0-1), orange (2-3) and red (4). This method, which assumes that both recharge indicators are equally important, provides a clear overview of potential groundwater recharge source areas in the Moscow sub-basin.

In order to provide a perspective of the importance on well depth and location relative to specific geologic features and groundwater recharge, a geological cross-section is provided of the well locations across the Moscow sub-basin (see Fig. 9). The well locations are simplified and schematically presented in the 2D cross-section. The color of each well represents the same recharge potential as used in Fig. 8d. In order to properly interpret these data, it is important to recognize that well logs indicate most of these wells pull groundwater from coarse interbeds below poorly permeable (e.g. thick clay) layers (Idaho Department of Water Resources 2013). The wells showing the strongest indications of recharge $(35,11,29$ and 14) are all located along the granite/basalt interface near Moscow Mountain and vary largely in depth (Figs. 8d and 9). The location of these wells agrees well with the simulated percolation maps from the SMR model. Further west towards Moscow, the indications of recharge decline, although both shallow springs exhibit strong indications of recharge $(6,19)$. These springs are likely supplied by upstream 


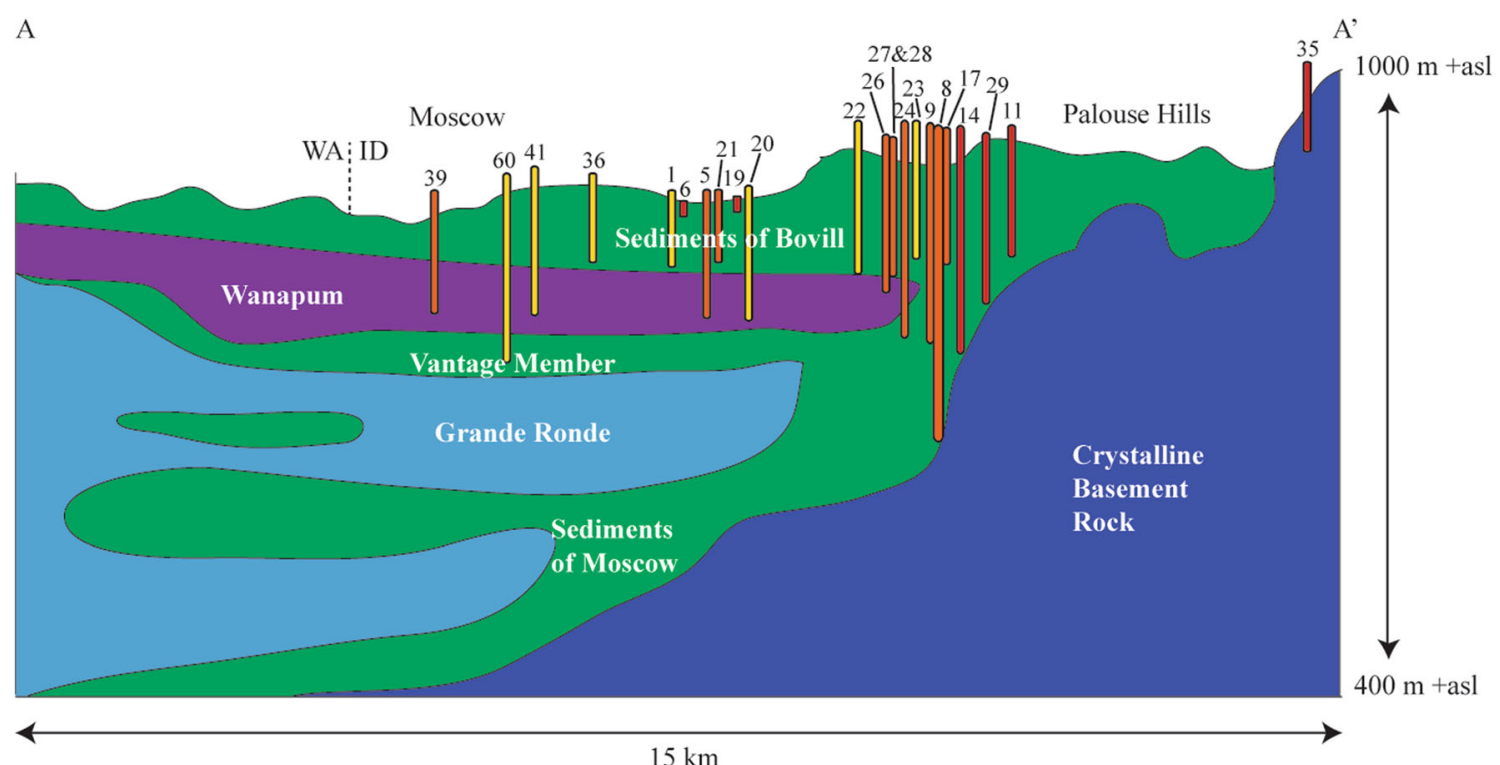

Fig. 9 Geological cross-section of the Moscow sub-basin (after Bush and Garwood 2005). All wells and springs have been included. The well locations are simplified and schematic. The numbers corresponds to the well sample ID. The well colours represent the same as in

Fig. 8d. Red is strong indications of recharge, orange is indications of recharge, yellow is no indications of recharge. Cross-section is based on approximate $\mathrm{W}-\mathrm{E}$ dashed line $\mathrm{A}-\mathrm{A}^{\prime}$ in Fig. 4

recharge. Some wells show no indications of recharge $(1,22,23$, 36). These wells are all relatively shallow and get water from the Sediments of Bovill, which lay above the Wanapum. As most of the water is recharged at the granite/basalt interface (arrow B and $\mathrm{C}$ in Fig. 2), a relatively small amount of water recharges the top of the Wanapum where these wells are located. The lack of recharge indications in these wells, combined with the SMR output, also underlines that little to no vertical percolation and recharge pathways occur in this region (arrow A in Fig. 2). Moreover, wells located relatively far from the recharging area do not exhibit any indications of recharge (see Wanapum and Vantage Member wells 20, 41 and 60); however, some Wanapum wells $(39,5)$ have indications of recharge, explained by the heterogeneity of the Wanapum aquifer (Leek 2006; McVay 2007; Bennett 2009). Overall, the isotope and modelling data both suggest that groundwater recharge is occurring at the basalt/granite interface near the forested uplands in the eastern fringe of the Moscow sub-basin. The well data suggest that this groundwater recharge flows laterally below the poorly permeable argillic horizons and thick clay deposits typically found in the lower agricultural production regions in the Moscow Sub-basin. This lateral flow likely occurs through complex coarse interbed layers or conduits at the granite/basalt interface where these geological units interfinger. Some of these lateral flow paths end up as surficial springs (Dijksma et al. 2011), whereas others likely recharge both aquifers. Other than the forested uplands, the modelling and isotope data indicate that little vertical percolation occurs over much of the Moscow sub-basin. This agrees well with the Fairley et al. (2006) groundwater characterization study which concluded little vertical recharge occurs over most of the
Moscow sub-basin due to the presence of widespread, thick clay deposits; however, this study provides added insight that the groundwater recharge is likely occurring as lateral flow beneath these clay deposits along the granite-basalt interface.

Temporally the $\delta^{18} \mathrm{O}$ peaks in groundwater are lagged and damped relative to $\delta^{18} \mathrm{O}$ peaks in precipitation. Although the dataset is relatively short, Fig. 7a indicates there is a $2-5$-week lag between a $\delta^{18} \mathrm{O}$ peak in precipitation and a $\delta^{18} \mathrm{O}$ peak in groundwater. This lagged $\delta^{18} \mathrm{O}$ suggests that the recharge response time may be as short as $2-5$ weeks. A longer more complete dataset would be required to determine a characteristic recharge response time for specific regions in the basin.

\section{Wider implications}

This study shows that permeable linear elements on the interface between impermeable (granitic) bedrock and permeable (basalt) formations can act as recharge pathways. Inducing recharge by artificial infiltration ponds may help to reduce the water level decline or even cause groundwater level rise in such basaltic aquifers. This principle also can be applied to other basaltic regions such as Deccan Traps. Isotope fractioning can help finding suitable locations for infiltration ponds.

\section{Conclusion}

Biweekly isotope measurements of 22 wells and two springs combined with a soil moisture routing (SMR) model showed strong indications of recharge in the proximity of the Moscow 
Mountain. The SMR model results suggest that precipitation percolates mainly at the Moscow Mountain, where maximum daily average percolation rates are reached (up to $2.0 \mathrm{~mm} \mathrm{~d}^{-1}$ ). The Moscow Mountain provides the source of aquifer recharge, from where water flows through lateral conduits below the poorly permeable layers recharging the basalt aquifers at the granite/basalt interface where these geological units interfinger. This study shows the importance of granite/ basalt interface areas for recharge to the basalt aquifers. These locations may be the main sources from where these types of aquifers receive recharge. As the local economy and many individuals depend on groundwater from basalt aquifers, these interface areas should be further explored towards the possibilities of using managed aquifer recharge and aquifer storage methods.

Acknowledgements This research is supported by the Palouse Basin Aquifer Committee (PBAC). Many thanks go to Steve Robischon for arranging the support by PBAC for this research. Furthermore, we thank Craig Woodruff and Todd Anderson for their support during the isotope sampling, as well as all well owners for letting us sampling their wells. Finally, thanks to the anonymous reviewers who gave great input and helped improve this article.

Open Access This article is distributed under the terms of the Creative Commons Attribution 4.0 International License (http:// creativecommons.org/licenses/by/4.0/), which permits unrestricted use, distribution, and reproduction in any medium, provided you give appropriate credit to the original author(s) and the source, provide a link to the Creative Commons license, and indicate if changes were made.

\section{References}

Amelung F, Galloway DL, Bell JW, Zebker HA, Laczniak RJ (1999) Sensing the ups and downs of Las Vegas: InSAR reveals structural control of land subsidence and aquifer-system deformation. Geology 27:483-486

Bara TJ, Shaw D (1995) Multi-resolution land characteristics consortium documentation notebook, ManTech Environmental Technology, Fairfax, VA

Barker RA (1979) Computer simulation and geohydrology of a basalt aquifer system in the Pullman-Moscow basin, Washington and Idaho. Washington Depart Ecol WaterSuppl Bull 48 1979, 119 pp

Bennett B (2009) Recharge implications of strategic pumping of the Wanapum Aquifer System in the Moscow sub-basin. University of Idaho, Moscow, ID

Brooks E, Grader G (2011) Recharge from east revisited. WSU GEOL 598 Seminar, Pullman, WA, March 2011

Brooks ES, Boll J (2005) A simple GIS-based snow accumulation and melt model. Proceedings of the 2005 Western Snow Conference, Great Falls, MT, p 11-14

Brooks ES, Boll J, McDaniel PA (2004) A hillslope-scale experiment to measure lateral saturated hydraulic conductivity. Water Resour Res 40(4)

Brooks ES, Boll J, McDaniel PA (2007) Distributed and integrated response of a geographic information system-based hydrologic model in the eastern Palouse region, Idaho. Hydrol Proc 21:110-122

Bush J (2005) The Columbia River Basalt Group of the Palouse Basin with hydrological interpretations, western Latah County, Idaho and eastern Whitman County, Washington. Idaho Geological Survey, Moscow, Idaho

Bush J, Garwood (2005) Various maps, and materials partly published as GSA abstracts, pieces of information not included in geologic maps. GSA, Boulder, CO

Candel J (2014) Identifying hydrologic recharge connections in the Moscow sub-basin. Wageningen University and Research Centre, Wageningen, The Netherlands

Cappa CD, Hendricks MB, DePaolo DJ, Cohen RC (2003) Isotopic fractionation of water during evaporation. J Geophys Res Atmos 108(D16), 4526

Carey L (2011) Evaluation of oxygen and hydrogen isotopes in groundwater of the Palouse Basin and Moscow sub-basin. University of Idaho, Moscow, ID

Changnon SA (1987) Detecting drought conditions in Illinois, Illinois State Water Survey, Champaign, IL

Craig H (1961) Isotopic variations in meteoric waters. Am Assoc AdvSci $1702-1703$

Dansgaard W (1964) Stable isotopes in precipitation. Tellus 16:436-468

De Graaf I (2011) Spatial and temporal distribution of subsurface water in the Paradise Creek Watershed. Wageningen University, Wageningen, The Netherlands

Dijksma R, Brooks ES, Boll J (2011) Groundwater recharge in Pleistocene sediments overlying basalt aquifers in the Palouse Basin, USA: modeling of distributed recharge potential and identification of water pathways. Hydrogeol J 19:489-500

Dillon P (2005) Future management of aquifer recharge. Hydrogeol J 13: $313-316$

Dillon P (2009) Water recycling via managed aquifer recharge in Australia. Bol Geol Minero 120:121-130

Eaton L, Melady J, Tolan T (2009) Successful implementation of ASR in basalt-hosted aquifers in the Pacific Northwest of the United States. Bol Geol Minero 120:131-156

El-Naqa A, Al-Momani M, Kilani S, Hammouri N (2007) Groundwater deterioration of shallow groundwater aquifers due to overexploitation in northeast Jordan. Clean Soil Air Water 35:156-166

Fairley J, Solomon M, Hinds J, Grader G, Bush J, Rand A (2006) Latah County hydrologic characterization project. Idaho Department of Water Resources, Boise, ID

Foglia L, Hill M C, Mehl SW, Burlando P (2009) Sensitivity analysis, calibration, and testing of a distributed hydrological model using error-based weighting and one objective function. Water Resour Res 45:W06427

Foster S, Garduno H, Evans R, Olson D, Tian Y, Zhang W, Han Z (2004) Quaternary aquifer of the North China Plain: assessing and achieving groundwater resource sustainability. Hydrogeol J 12:81-93

Frankenberger JR, Brooks ES, Walter MT, Walter MF, Steenhuis TS (1999) A GIS-based variable source area hydrology model. Hydrol Proc 13:805-822

Froehlich K, Gibson J, Aggarwal P (2001) Deuterium excess in precipitation and its climatological significance: study of environmental change using isotope techniques. In: Proc. Int. Conf. Study ofEnvironmental ChangeUsing Isotope Techniques, Vienna, April 2001, pp 54-66

Gale I, Macdonald D, Calow R, Neumann I, Moench M, Kulkarni H, Mudrakartha S, Palanisami K (2006) Managed aquifer recharge: an assessment of its role and effectiveness in watershed management: final report for DFID KAR project R8169, Augmenting groundwater resources by artificial recharge: AGRAR. British Geological Survey, Keyworth, UK

Gerges N, Dillon P, Sibenaler X, Martin R, Pavelic P, Howles S, Dennis K (2002) South Australian experience in aquifer storage and recovery. In: Dillon PJ (ed) Management of aquifer recharge for sustainability. Balkema, Rotterdam, The Netherlands, pp 453-458 
Grader G (2011) Miocene Latah Formation and subsurface geology along the Moscow Subbasin margin: "Recharge from the east" revisited. PRISEM, Spokane, WA

Hansen AJ, Vaccaro JJ, Bauer HH (1994) Ground-water flow simulation of the Columbia Plateau regional aquifer system, Washington, Oregon, and Idaho. US Geol Surv Water Resour Invest Rep 91-4187

Hayashi T, Tokunaga T, Aichi M, Shimada J, Taniguchi M (2009) Effects of human activities and urbanization on groundwater environments: an example from the aquifer system of Tokyo and the surrounding area. Sci Total Environ 407:3165-3172

Hooper PR (1982) The Columbia River basalts. Science 215:1463-1468

Hoque MA, Hoque MM, Ahmed KM (2007) Declining groundwater level and aquifer dewatering in Dhaka metropolitan area, Bangladesh: causes and quantification. Hydrogeol J 15:1523-1534

Idaho Department of Water Resources (2013) Well Log Database. IDWR, Boise, ID

Johnson MS, Coon WF, Mehta VK, Steenhuis TS, Brooks ES, Boll J (2003) Application of two hydrologic models with different runoff mechanisms to a hillslope dominated watershed in the northeastern US: a comparison of HSPF and SMR. J Hydrol 284:57-76

Katsuyama M, Tani M, Nishimoto S (2010) Connection between streamwater mean residence time and bedrock groundwater recharge/discharge dynamics in weathered granite catchments. Hydrol Proc 24:2287-2299

Kendall C, MacDonnell JJ (1998) Isotope tracers in catchment hydrology. Elsevier, Amsterdam

Konikow LF, Kendy E (2005) Groundwater depletion: a global problem. Hydrogeol J 13:317-320

Laney F, Kirkham V, Piper A (1923) Ground-water supply at Moscow, Idaho. Pamphlet 8, Idaho Bur. Min, Boise, ID

Larson KR, Keller CK, Larson PB, Allen-King RM (2000) Water resource implications of $18 \mathrm{O}$ and $2 \mathrm{H}$ distributions in a basalt aquifer system. Groundwater 38:947-953

Leek F (2006) Hydrogeological characterization of the Palouse Basin Basalt Aquifer system, Washington and Idaho. Washington State University, Pullman, WA

Lum W, Smoot JL, Ralston DR (1990) Geohydrology and numerical model analysis of ground-water flow in the Pullman-Moscow area, Washington and Idaho. US Geol Surv Invest Rep 89-4103

Macdonald D, Kulkarni H, Lawrence A, Deolankar S, Barker J, Lalwani A (1995) Sustainable groundwater development of hard-rock aquifers: the possible conflict between irrigation and drinking water supplies from the Deccan basalts of India. NERC Technical Report WC/95/52, BGS, Keyworth, UK

Maliva RG, Herrmann R, Coulibaly K, Guo W (2014) Advanced aquifer characterization for optimization of managed aquifer recharge. Environ Earth Sci 73:7759-7767

McDaniel P, Regan M, Brooks E, Boll J, Barndt S, Falen A, Young S, Hammel J (2008) Linking fragipans, perched water tables, and catchment-scale hydrological processes. Catena 73:166-173

McDonnell JJ, Kendall C (1992) Isotope tracers in hydrology. Elsevier, Amsterdam, pp 260-261

McVay M (2007) Grande Ronde aquifer characterization in the Palouse Basin: MSc Thesis, University of Idaho, Moscow, ID

Mehta VK, Walter MT, Brooks ES, Steenhuis TS, Walter MF, Johnson M, Boll J, Thongs D (2004) Application of SMR to modeling watersheds in the Catskill Mountains. Environ Model Assess 9:77-89

Moxley N (2012) Stable isotope analysis of surface water and precipitation in the Palouse basin: hydrologic tracers of aquifer recharge. MSc Thesis, Washington State University, Pullman, WA

Nash JE, Sutcliffe JV (1970) River flow forecasting trough conceptual models, part I: a discussion of principles. J Hydrol (Amsterdam) 10: 282-290

Othberg KL, Breckenridge RM, Freed JS, Stanford LR (2001) Surficial geologic map of the Moscow East Quadrangle and part of the
Moscow West Quadrangle, Latah County, Idaho. Idaho Geological Survey, University of Idaho, Boise, ID

Pavelic P, Patankar U, Acharya S, Jella K, Gumma MK (2012) Role of groundwater in buffering irrigation production against climate variability at the basin scale in South-West India. Agri Water Manage 103:78-87

Qureshi AS, McCornick PG, Sarwar A, Sharma BR (2010) Challenges and prospects of sustainable groundwater management in the Indus Basin, Pakistan. Water Resour Manage 24:1551-1569

Rahman MA, Rusteberg B, Gogu R, Ferreira JL, Sauter M (2012) A new spatial multi-criteria decision support tool for site selection for implementation of managed aquifer recharge. J Environ Manage 99: $61-75$

Reidel SP, Martin BS, Petcovic HL (2003) The Columbia River flood basalts and the Yakima fold belt: Western Cordillera and adjacent areas. In: Swanson TW (ed) Geological Society of America Field Guide. GSA, Boulder, CO, pp 87-105

Robischon S (2006) 2002-2005 Palouse Groundwater Basin Use Report Moscow (ID). Palouse Basin Aquifer Committee, Moscow, ID

Robischon S (2007) Palouse Basin Ground Water Management: a history. Palouse Basin Water Summit, Moscow, ID

Sánchez-Murillo R, Brooks ES, Elliot WJ, Boll J (2015) Isotope hydrology and baseflow geochemistry in natural and human-altered watersheds in the Inland Pacific Northwest, USA. Isotopes Environ Health Stud 51:231-254

Scanlon BR, Healy RW, Cook PG (2002) Choosing appropriate techniques for quantifying groundwater recharge. Hydrogeol J 10:18-39

Shah T, Molden D, Sakthivadivel R, Seckler D (2000) Groundwater: overview of opportunities and challenges. IWMI, Colombo, Sri Lanka

Soulsby C, Tetzlaff D (2008) Towards simple approaches for mean residence time estimation in ungauged basins using tracers and soil distributions. J Hydrol 363:60-74

Speed M, Tetzlaff D, Soulsby C, Hrachowitz M, Waldron S (2010) Isotopic and geochemical tracers reveal similarities in transit times in contrasting mesoscale catchments. Hydrol Proc 24:1211-1224

Tolan TL, Reidel SP, Beeson MH, Anderson JL, Fecht KR, Swanson DA (1989) Revisions to the estimates of the areal extent and volume of the Columbia River Basalt Group. GSA, Boulder, CO, pp 1-20

US Geological Survey (2012) Discharge measurements 1935-2012. US Geological Survey, Reston, VA

UNESCO (2009) The United Nations World Water Development report 3: water in a changing world. Earthscan, UNESCO, Paris

Vaccaro JJ (1999) Summary of the Columbia Plateau regional aquifersystem analysis, Washington, Oregon, and Idaho. US Geological Survey, Reston, VA

Van Loon A F, Gleeson T, Clark J, Van Dijk AIJM, Stahl K, Hannaford J, Di Baldassarre G, Teuling AJ, Tallaksen LM, Uijlenhoet R, Hannah DM, Sheffield J, Svoboda M, Verbeiren B, Wagener T, Rangecroft S, Wanders N, Van Lanen HAJ (2016) Drought in the Anthropocene. Nature Geosci 9:89-91

Wada Y, Beek L, Bierkens M F (2012) Nonsustainable groundwater sustaining irrigation: a global assessment. Water Resour Res 48(6): W06901

Wassenaar L, Athanasopoulos P, Hendry M (2011) Isotope hydrology of precipitation, surface and ground waters in the Okanagan Valley, British Columbia, Canada. J Hydrol 411:37-48

Whiteman K, Vaccaro J, Gonthier JB, Bauer HH (1994) The hydrogeologic framework and geochemistry of the Columbia Plateau aquifer system, Washington, Oregon, and Idaho. US Geol Surv Prof Pap 1413-B

Willis KG, Garrod GD (1998) Water companies and river environments: the external costs of water abstraction. Utilities Pol 7:35-45

WRCC (2013) Monthly climate averages of Idaho, 1893-2013. WRCC, Sun Valley, NV 